\title{
Kasabach-Merritt Syndrome in an Adult: A Comment
}

\author{
Erişkin Bir Hastada Kasabach-Merritt Sendromu: Bir Yorum
}

(D) Sevgi Gözdaşoğlu

Retired Professor

To the Editor,

I read with interest the article by Vinod et al. [1] entitled "Kasabach-Merritt Syndrome in an Adult" in a recent issue of the Turkish Journal of Hematology.

Related to this article, I would like to add that Özsoylu [2] reported megadose methylprednisolone (MDMP) treatment for different hematological conditions including hemangiomas, infantile hemangiomatosis, and Kasabach-Merritt syndrome. Özsoylu [2] recommended the daily use of MDMP at $30 \mathrm{mg} / \mathrm{kg}$ for 3 days, then $20 \mathrm{mg} / \mathrm{kg}$ for 4 days and subsequently $10,5,2$, and $1 \mathrm{mg} / \mathrm{kg}$ with each dose administered for 1 week around $6 \mathrm{AM}$ as a single dose [2,3]. Özsoylu [2] treated patients who were resistant to conventional corticosteroid treatment either orally or intravenously over the course of 10-15 min [2,3]. Conventional corticosteroid treatment and MDMP were comparatively studied for the treatment of hemangiomas and it was observed that MDMP was superior [4].

In our department, eight patients with infantile hemangiomas were treated with interferon- $\alpha 2$ a plus oral prednisolone without observing severe complications. In this study, the median age was 4 months (range: 3-12 months); six of them were female and two were male. Three cases were not followed and three patients achieved complete regression while a partial regression was observed in two others. The beneficial results were obtained with interferon- $\alpha 2$ a plus oral prednisolone treatment in these cases [5].

On the other hand, vascular endothelial growth factor (VEGF) is recognized as an essential regulator of blood vessel growth. The use of anti-VEGF abolishes this vascular endothelial growth-promoting activity in vitro [6]. Three patients with periocular epithelioid hemangioma were treated with antiVEGF successfully [7]. Although recent studies have indicated the effectiveness of anti-VEGF treatment in these cases, there is not a significant number of clinical trials reported.

Keywords: Megadose methylprednisone, Kasabach-Merritt Syndrome, VEGF

Anahtar Sözcükler: Megadoz metilprednizon, Kasabach-Merritt Sendromu, VEGF

Conflict of Interest: The author of this paper has no conflicts of interest including specific financial interests, relationships, and/or affiliations relevant to the subject matter or materials included.

\section{References}

1. Vinod KV, Johny J, Vadivelan M, Hamide A. Kasabach-Merritt syndrome in an adult. Turk J Hematol 2018;35:204-205.

2. Özsoylu Ş. Megadose methyl-prednisolone (MDMP) for hemangiomatosis. Turk J Hematol 2012;29:436-437.

3. Özsoylu Ş. About the treatment of Kasabach-Merritt syndrome. Turk J Hematol 2013;30:94.

4. Uysal KM, Olgun N, Erbay A, Sarıalioğlu F. High-dose oral methylprednisolone therapy in childhood hemangiomas. Pediatr Hematol Oncol 2001;18:335341.

5. Gözdaşoğlu S, Uysal Z, Ertem M, Suskan E, Kürekci E, İleri T, Azık F, Cin Ş. Bebeklik çağı Hemanjiomlarında interferon - $\alpha$ 2a tedavisi. In: IV. Ulusal Pediatrik Hematoloji Kongresi, 10-13 September Trabzon, Turkey, 2003.

6. Mahajan D, Miller C, Hirose K, McCullough A, Yerian L. Incidental reduction in the size of liver hemangioma following use of VEGF inhibitor bevacizumab. J Hepatol 2008:49:867-870.

7. Kahana A, Lee BJ, Flint A, Elner VM. Periocular epithelioid hemangioma: response to bevacizumab and vascular pathogenesis. JAMA Ophthal 2012;130:1209-1212.

๑Copyright 2019 by Turkish Society of Hematology

Turkish Journal of Hematology, Published by Galenos Publishing House 


\title{
Reply to the Authors
}

\section{Dear Editor,}

We would like to thank Gözdaşoğlu [1] for showing interest in our report of adult Kasabach-Merritt syndrome (KMS) [2]. Being adult hematologists, we should admit that we have limited experience with treatment of KMS, which by and large affects infants and young children. We do not have personal experience with interferon-alpha and have not studied the efficacy of different corticosteroids in different doses and combination of prednisolone with interferon-alfa for treatment of KMS. In this regard, we thank Gözdaşoğlu [1] for sharing her personal experience (effectiveness of prednisolone + interferon-alfa 2a combination therapy) with treatment of infantile hemangiomas and also for highlighting on reports of usefulness of high dose methylprednisolone [3] and anti-VEGF (bevacizumab) therapy for treatment of hemangiomas and KMS. Clinical trials evaluating different therapies would be desirable in the future to clarify on optimal treatment of KMS.

Best Regards,

Kolar Vishwanath Vinod, Joseph Johny, Mehalingam Vadivelan, Abdoul Hamide

\section{References}

1. Gözdaşoğlu S. Kasabach-Merritt Syndrome in an Adult: A Comment. Turk J Hematol 2019;36:52.

2. Vinod KV, Johny J, Vadivelan M, Hamide A. Kasabach-Merritt Syndrome in an adult. Turk J Hematol 2018;35:204-205.

3. Uysal KM, Olgun N, Erbay A, Sarıolioğlu F. High-dose oral methylprednisolone therapy in childhood hemangiomas. Pediatr Hematol Oncol 2001;18:335-341.

\section{Bendamustine and Rituximab Treatment, Chronic Lymphocytic Leukemia, Direct Antiglobulin Test, and False Negatives}

\author{
Bendamustin ve Rituksimab Tedavisi, Kronik Lenfositik Lösemi, Direkt Antiglobulin Test ve \\ Yanlış Negatiflik
}

\author{
(D) Won Sriwijitalai1, (D) Viroj Wiwanitkit² \\ 1 TWS Medical Center, Bangkok, Thailand \\ ${ }^{2}$ Dr. DY Patil University, Pune, India
}

To the Editor,

We read "Early Direct Antiglobulin Test Negativity After Bendamustine and Rituximab Treatment in Chronic Lymphocytic Leukemia: Two Cases" [1]. Eren and Suyanı noted that "BR seems to be an important treatment of choice in terms of eliminating the poor prognostic factor of direct antiglobulin test (DAT) positivity and assuring safe cessation of steroid treatment due to rapid achievement of DAT negativity" [1]. The interesting observation of a negative DAT test should be discussed. There is another possibility that Eren and Suyanı did not mention. In their report, Eren and Suyanı noted that no titer was provided [1]. Whether the negative result is a false negative result should be discussed. For DAT testing, the prozone phenomenon is observable and it is important to consider this phenomenon in the interpretation of unexpected false negative DAT tests $[2,3,4]$.

Keywords: Bendamustine, Rituximab, Leukemia, Direct antiglobulin test, False negatives

Anahtar Sözcükler: Bendamustin, Rituksimab, Lösemi, Direkt antiglobulin testi, Yanlış negatiflik

Conflict of Interest: The authors of this paper have no conflicts of interest, including specific financial interests, relationships, and/or affiliations relevant to the subject matter or materials included. 